\title{
PENGARUH SISTEM INFORMASI AKUNTANSI DAN SISTEM PENGENDALIAN INTERNAL TERHADAP KINERJA PERUSAHAAN (STUDI KASUS PADA KOPERASI DI KECAMATAN PAYANGAN)
}

\author{
Putu Ayu Yohana Putri* dan I Dewa Made Endiana \\ Fakultas Ekonomi dan Bisnis Universitas Mahasaraswati, Denpasar, Bali-Indonesia \\ *yohanaputri@gmail.com
}

DiPublikasi: 01/01/2020

http://dx.doi.org/10.22225/kr.11.2.1433.179-189

\begin{abstract}
One important function of the accounting information system is internal control. The weak internal control system in several cooperatives in Payangan District also results in employees having the opportunity to commit fraud that can harm the company. Performance is the result of work achieved by employees in carrying out tasks in accordance with their responsibilities. Through the achievement of each individual, the company can produce complete performance and achieve success in accordance with what is expected by the company. To improve cooperative performance, it is very important to know the effect of applying accounting information systems and internal controls in improving company performance and increasing company productivity. The population in this study amounted to 531 cooperative members who work at cooperatives in Payangan District. Sampling uses a purposive sampling method and the test tool used is multiple linear regression analysis. The results of this study prove that the accounting information system has no effect on company performance while the internal control structure has a positive effect on company performance.
\end{abstract}

Keywords: Accounting information system; internal control structure

Abstrak

Salah satu fungsi penting dari sistem informasi akuntansi adalah pengendalian internal. Lemahnya sistem pengendalian internal di beberapa koperasi yang ada di Kecamatan Payangan juga mengakibatkan karyawan memiliki kesempatan untuk melakukan kecurangan yang dapat merugikan perusahaan. Kinerja merupakan hasil kerja yang dicapai oleh karyawan dalam melakukan tugas sesuai dengan tanggung jawabnya. Melalui pencapaian masing-masing individu maka perusahaan dapat menghasilkan kinerja seutuhnya dan mencapai keberhasilan sesuai dengan apa yang diharapkan perusahaan. Untuk meningkatkan kinerja koperasi sangatlah penting untuk mengetahui pengaruh penerapan sistem informasi akuntansi dan pengendalian internal dalam meningkatkan kinerja perusahaan dan meningkatkan produktivitas perusahaan. Populasi pada penelitian ini berjumlah 531 anggota koperasi yang bekerja pada koperasi di Kecamatan Payangan. Pengambilan sampel menggunakan metode purposive sampling dan alat uji yang digunakan adalah analisis regresi linear berganda. Hasil penelitian ini membuktikan bahwa sistem informasi akuntansi tidak berpengaruh terhadap kinerja perusahaan sedangkan struktur pengendalian internal berpengaruh positif terhadap kinerja perusahaan.

Kata Kunci: Sistem informasi akuntansi; struktur pengendalian internal

\section{PENDAhUluAN}

Pada era globalisasi seperti sekarang ini penerapan sistem informasi akuntansi dalam lembaga keuangan semakin berkembang pesat, tidak hanya di perbankan tetapi juga di lembaga keuangan lain seperti koperasi. Sistem informasi akuntansi yang digunakan oleh koperasi lebih sederhana dibandingkan dengan sistem informasi akuntansi yang digunakan oleh perbankan. Setiap koperasi pasti memiliki visi dan misi yang bertujuan untuk menjadikan koperasi tersebut menjadi lebih baik. Untuk mewujudkan visi dan misi yang dimiliki oleh seiap koperasi maka perlu adanya strategi dengan kinerja karyawan di setiap koperasi itu sendiri. Tetapi setelah dilakukan wawancara dengan ketua pada beberapa koperasi yang ada di Kecamatan Payangan, masih terdapat beberapa kinerja karyawan yang dinilai kurang serta tidak sesuai dengan visi dan misi yang dimiliki oleh masing-masing koperasi yang bersangkutan seperti karyawan tidak menjalankan sistem informasi akuntansi dengan baik dan karyawan tidak mematuhi sistem pengendalian internal yang ada pada masing-masing koperasi tersebut. Sistem tentunya sangat dibutuhkan untuk menopang suatu perusahaan agar tetap kokoh. Sistem adalah rangkaian dua atau lebih komponen-komponen yang saling berhubungan, yang berinteraksi untuk mencapai suatu tujuan (Romney \& Steinbart, 2015). Salah satu fungsi penting dari sistem informasi akuntansi adalah 
pengendalian internal. Salah satu objek dari pengendalian internal adalah kinerja perusahaan dan kinerja individu di dalamnya. Pengukuran kinerja dapat menggunakan "input-proses-output" dengan menggunakan indikator prestasi kerja, kerja sama, dan tanggung jawab.

Tanpa didukung oleh tenaga kerja yang memadai, suatu perusahaan tidak dapat menjalankan aktivitasnya secara efektif dan efisien dalam rangka pencapaian tujuannya, oleh karena itu pimpinan suatu perusahaan harus selalu berusaha untuk meningkatkan kualitas dan kuantitas sumber daya manusianya agar perusahaan dapat mencapai tujuan yang telah ditetapkan. Kurangnya tanggung jawab karyawan dalam menggunakan sistem informasi akuntansi juga dapat mengakibatkan informasi yang dihasilkan tidak sesuai dengan yang sebenarnya. Sehingga laporan keuangan yang dihasilkan tidak relevan dan reliabel.

Lemahnya sistem pengendalian internal di beberapa koperasi yang ada di Kecamatan Payangan juga mengakibatkan karyawan memiliki kesempatan untuk melakukan kecurangan yang dapat merugikan perusahaan. Untuk menghasilkan kinerja yang optimal dalam suatu perusahaan dapat diukur dari hasil pekerjaan yang telah dilakukan oleh karyawan dibandingkan dengan standar yang telah ditetapkan oleh perusahaan, karena keberhasilan suatu organisasi dipengaruhi oleh kinerja karyawan. Kinerja merupakan hasil kerja yang dicapai oleh karyawan dalam melakukan tugas sesuai dengan tanggung jawabnya. Melalui pencapaian masing-masing individu maka perusahaan dapat menghasilkan kinerja seutuhnya dan mencapai keberhasilan sesuai dengan apa yang diharapkan perusahaan. Menurut (Suswardji, Hasbullah, \& Albatross, 2012) untuk mencapai keberhasilan diperlukan landasan yang kuat, salah satunya kompetensi, baik kompetensi karyawan, pimpinan dan organisasi dengan begitu dapat diketahui bahwa kompetensi sangat penting untuk mencapai suatu tujuan dalam organisasi dengan sukses.

\section{TINJAUAN PUSTAKA}

\section{Teori Keagenan (Agency Theory)}

Hubungan keagenan adalah sebuah kontrak antara manajer (agent) dengan investor (principal) (Jensen \& Meckling, 1976). Terjadinya konflik kepentingan antara pemilik dengan agent karena kemungkinan agen bertindak tidak sesuai dengan kepentingan principal, sehingga memicu biaya keagenan (agency cost).

Pemilik memiliki kepentingan agar dana yang telah diinvestasikannya memberikan pendapatan yang maksimal, sedangkan pihak manajemen memiliki kepentingan terhadap perolehan incentives atas pengelolaan dana pemilik perusahaan. Konflik kepentingan ini akan menimbulkan biaya (cost) yang biasa disebut dengan agency cost.

Kinerja perusahaan sangat berkaitan dengan bagaimana membuat para investor yakin bahwa manajer atau karyawan akan memberikan keuntungan bagi mereka, yakni karyawan tidak akan mencuri, memanipulasi laporan keuangan, menggelapkan atau menginvestasikan ke dalam proyek-proyek yang tidak menguntungkan berkaitan dengan dana yang telah ditanamkan investor. Pengendalian internal merupakan mekanisme efektivitas yang mempunyai tujuan untuk meminimalisasi konflik keagenan.

\section{Technology Acceptance Model (TAM)}

Teori TAM yang diperkenalkan oleh (Davis, 1989) dibangunan untuk menjelaskan bagaimana pengguna atau user dapat menerima suatu teknologi dalam sistem informasi. TAM juga merinci factor-faktor apa saja yang dapat mempengaruhi penerimaan suatu teknologi dalam sistem informasi tersebut. TAM merupakan pengembangan dari Theory Reasoned Action yang diperkenalkan oleh (Ajzen \& Fishbein, 1980).

Penggunaan Technology Accepted Model (TAM) sebagai salah satu landasan teori dalam penelitian ini adalah untuk menganalisis pengaruh Sistem Informasi Akuntansi terhadap kinerja perusahaan yang sesuai dengan Technology Accepted Model (TAM).

\section{Kinerja Perusahaan}

Pengertian kinerja atau performance merupakan gambaran mengenai tingkat pencapaian pelaksanaan suatu program kegiatan atau kebijakan dalam mewujudkan sasaran, tujuan, visi, dan misi organisasi yang dituangkan melalui perencanaan strategis suatu organisasi (Moeheriono, 2012).

Kinerja perusahaan merupakan sesuatu yang dihasilkan oleh suatu perusahaan dalam periode tertentu dengan mengacu kepada standar yang ditetapkan. Pengukuran aktivitas kinerja 
perusahaan dirancang untuk menaksir bagaimana kinerja aktivitas dan hasil akhir yang dicapai. Menurut (Helfert, 1996) kinerja perusahaan adalah sebuah hasil yang dibuat oleh pihak manajemen secara terus menerus. Dalam hal ini, hasil yang dimaksud merupakan hasil dari keputusan banyak individu. Tujuan kinerja perusahaan adalah untuk memotivasi personel mencapai sasaran organisasi dan mematuhi standar perilaku yang telah diterapkan sebelumnya, agar membuahkan tindakan dan hasil yang diinginkan oleh organisasi (Chairany \& Lestari, 2011).

\section{Penilaian Kinerja}

Penilaian kinerja aktivitas perusahaan dibagi dalam tiga dimensi utama yaitu efisiensi, kualitas dan waktu. Penilaian kinerja sendiri memiliki beberapa pengertian yaitu Suatu sistem formal dan terstruktur yang mengukur, menilai, dan mempengaruhi sifat-sifat yang berkaitan dengan pekerjaan, perilaku, dan hasil termasuk tingkat ketidak hadiran. Fokusnya adalah untuk mengetahui seberapa produktif seorang karyawan dan apakah ia bisa berkinerja sama atau lebih efektif pada masa yang akan datang, sehingga karyawan, organisasi, dan masyarakat semuanya memperoleh manfaat (Schuler \& Jackson, 1996). Pencapaian tujuan yang telah ditetapkan merupakan salah satu tolak ukur kerja individu.

\section{Tujuan Penilaian Kinerja Perusahaan}

Tujuan penilaian kinerja perusahaan adalah sebagai berikut (Munawir, 2000): 1) Untuk mengetahui tingkat likuiditas, yaitu kemampuan perusahaan untuk memperoleh kewajiban keuangan-keuangannya yang harus segera dipenuhi atau kemampuan perusahaan untuk memenuhi keuangannya pada saat ditagih. 2) Untuk mengetahui tingkat solvabilitas, yaitu kemampuan perusahaan untuk memenuhi kewajiban keuangannya apabila perusahaan tersebut dilikuidasi baik kewajiban keuangan jangka pendek maupun jangka panjang. 3) Untuk mengetahui tingkat rentabilitas atau profitabilitas, yaitu menunjukkan kemampuan perusahaan untuk menghasilkan laba selama periode tertentu. 4) Untuk mengetahui tingkat stabilitas usaha, yaitu kemampuan perusahaan untuk melakukan usahanya dengan stabil, yang diukur dengan mempertimbangkan kemampuan perusahaan untuk membayar beban bunga atas hutanghutangnya termasuk membayar kembali pokok hutangnya tepat pada waktunya serta kemampuan membayar deviden secara teratur kepada para pemegang saham tanpa mengalami hambatan atau krisis keuangan.

\section{Aspek-aspek Kinerja Perusahaan}

Pengukuran kinerja adalah penentuan secara periodik efektivitas operasional suatu organisasi dan personelnya berdasarkan sasaran, standar, dan kriteria yang telah ditetapkan sebelumnya (Susanto, Taman, \& Sukirno, 2004). Tujuan utama pengukuran kinerja adalah memotivasi personel dalam mencapai sasaran perusahaan dan dalam mematuhi standar perilaku yang telah ditetapkan sebelumnya agar membuahkan tindakan dan hasil yang diinginkan oleh perusahaan.

Ada berbagai macam metode pngukuran kinerja perushaan yang dapat digunakan. Wade et al dalam penelitiannya mengukur kinerja perusahaan dari sisi keuangan (Accounting Measures) yaitu dengan menggunakan Market Return dan Return on Common Equity (ROE). Untuk menghitung Market Return sebagai total saham tahunan perusahaan, dengan asumsi deviden di investasi ulang, Wade et al menggunakan formula (Price $_{\text {end }}-$ price $_{\text {beginning }}+$ dividends)/ price beginning. $_{\text {ROE digunakan untuk }}$ mengukur seberapa baik sebuah perusahaan menggunakan modal yang disediakan oleh pemegang saham.

Perubahan dunia bisnis menyebabkan kinerja keuangan tidak lagi memadai dalam mengukur kinerja perusahaan. Perusahaan memerlukan metode yang dapat mengukur kinerja perusahaan secara menyeluruh. Balanced Scorecard yang dipelopori oleh (Kaplan \& Norton, 1996) merupakan metode pengukuran kinerja perusahaan yang menitikberatkan pada aspek finansial dan non finansial.

Balanced Scorecard terdiri dari dua kata: (1) Kartu Skor (scorecard), (2) Berimbang (balanced). Balanced Scorecard adalah suatu sistem manajemen, pengukuran, dan pengendalian yang dapat memberikan pemahaman kepada manajer tentang performa bisnis dalam perspektif keuangan, customer, proses bisnis internal dan pembelajaran dan pertumbuhan.

\section{Sistem Informasi Akuntansi}

\section{Pengertian Sistem Informasi Akuntansi}

Sistem informasi akuntansi adalah kumpulan sumber daya, seperti manusia dan peralatan, yang 
dirancang untuk mengubah data keuangan dan data lainnya menjadi informasi yang akan dikomunikasikan kepada berbagai pihak pengambil keputusan (Bodnar \& Hopwood, 2003), Sedangkan (Diana \& Setiawati, 2011) mendefinisikan sistem informasi akuntansi adalah sistem yang bertujuan untuk mengumpulkan dan memproses data serta melaporkan informasi yang berkaitan dengan transaksi keuangan.

\section{Tujuan Sistem Informasi Akuntansi}

Tujuan sistem informasi akuntansi, yaitu (Diana \& Setiawati, 2011); 1) Mengamankan harta/kekayaan perusahaan. Harta/kekayaan di sini meliputi kas perusahaan, persediaan barang dagang, termasuk asset tetap perusahaan, 2) Menghasilkan beragam informasi untuk pengambilan keputusan, 3) Menghasilkan informasi untuk pihak eksternal, 4) Menghasilkan informasi untuk penilaian kinerja karyawan atau divisi, 5) Menyediakan data masa lalu untuk kepentingan audit, 6) Menghasilkan informasi untuk penyusunan dan evaluasi anggaran perusahaan dan 7) Menghasilkan informasi yang diperlukan dalam kegiatan perencanaan dan pengendalian.

\section{Komponen-komponen Sistem Informasi Akuntansi}

Menurut (Romney \& Steinbart, 2015) ada enam komponen sistem informasi akuntansi, yaitu: Orang yang menggunakan sistem, 2) Prosedur dan instruksi yang digunakan untuk mengumpulkan, memproses, dan menyimpan data, 3) Data mengenai organisasi dan aktivitas bisnisnya, 4) Perangkat lunak yang digunakan untuk mengolah data, 5) Infrastruktur teknologi informasi, meliputi komputer, perangkat peripheral, dan perangkat jaringan komunikasi yang digunakan dalam sistem informasi akuntansi, dan 6) Pengendalian internal dan pengukuran keamanan yang menyimpan data sistem informasi akuntansi.

\section{Sistem Pengendalian Internal}

Pengertian Sistem Pengendalian Internal

Sistem pengendalian internal didefinisikan oleh AICPA (American Institue Of Certified Public Accountants) dalam (Hall, 2001) sebagai struktur suatu organisasi dan semua metodemetode yang terorganisasi serta ukuran-ukuran yang ditetapkan dalam suatu perushaan untuk tujuan menjaga keamanan harta kekayaan milik perusahaan, memeriksa ketepatan dan kebenaran data akuntansi, meningkatkan efisiensi operasi kegiatan dan mendorong ditaatinya kebijakan yang telah ditetapkan.

COSO (The Committee Of Spnsoring Organizations Of Treadway Commission) sebagai suatu inisiatif dari sector swasta yang dibentuk pada tahun 1985. Pada tahun 1992, COSO yang didirikan dengan tujuan utama untuk mengidentifikasi faktor-faktor yang menyebabkan penggelapan laporan keuangan dan membuat rekomendasi untuk mengurangi kejadian tersebut telah menerbitkan Internal Control Freamework yang didalamnya disusun definisi umum untuk pengendalian internal, standar, dan kriteria pengendalian internal yang dapat digunakan perusahaan menilai sistem pengendalian mereka.

\section{Elemen-elemen Sistem Pengendalian Internal}

Penerapan sistem pengendalian internal di dalam suatu perusahaan tergantung dari situasi serta jenis dari perusahaan. Sistem pengendalian internal mempunyai 6 elemen dasar, yaitu (Hall, 2001) Karyawan yang jujur dan cakap, Adanya pemisahan tugas dengan garis wewenang dan tanggung jawab yang jelas, Prosedur yang tepat untuk pemberian wewenang dan Dokumen dan catatan yang lengkap

Komponen-komponen Pengendalian Internal

Menurut Committee of Sponsoring Organization of the Treadway Commission (COSO) dalam (Halim, 2008) pengendalian internal satuan usaha terdiri atas komponenkomponen Lingkungan Pengendalian, Penilaian Resiko, Informasi dan Komunikasi, Aktivitas Pengendalian dan Pemantauan

\section{Keterbatasan Pengendalian Internal}

Pengendalian internal di setiap entitas memiliki keterbatasan bawaan, pengendalian internal hanya memberikan keyakinan memadai, bukan mutlak kepada manajemen dan dewan komisaris tentang tujuan entitas (Mulyadi, 2002). Keterbatasan bawaan yang terdapat dalam setiap pengendalian internal yang terdiri dari; 1) Kesalahan dalam pertimbangan, 2)Gangguan, 3) Kolusi, 4) Pengabaian Manajemen dan 5)Biaya dan Manfaat

\section{Rumusan Hipotesis}

H1 : Sistem informasi akuntansi berpengaruh positif terhadap kinerja perusahaan.

$\mathrm{H} 2$ : Sistem pengendalian internal berpengaruh positif terhadap kinerja perusahaan 
Pengaruh Sistem Informasi Akuntansi Dan Sistem Pengendalian Internal Terhadap Kinerja Perusahaan (Studi Kasus Pada Koperasi Di Kecamatan Payangan)

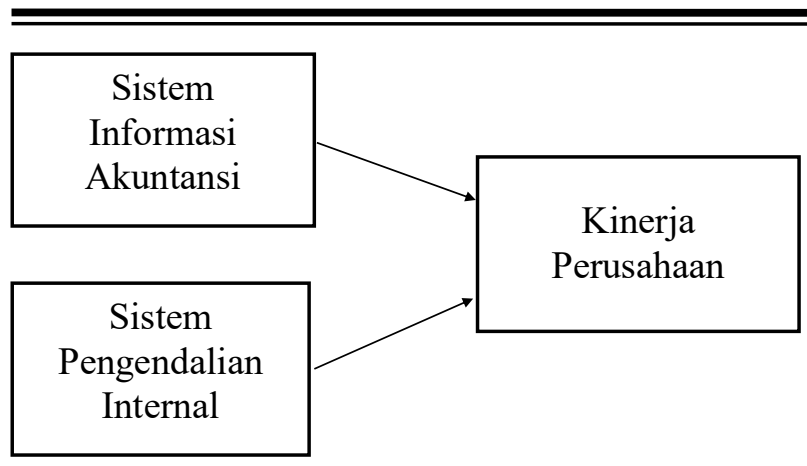

Diagram 1

Hipotesis Penelitian

\section{METODE}

Penelitian dilakukan di 105 koperasi yang ada di Kecamatan Payangan. Obyek penelitian adalah anggota koperasi yang bekerja pada koperasi di Kecamatan Payangan. Variabel yang digunakan dalam penelitian ini terdiri dari; 1) Variabel bebas dimana disebut variabel yang mempengaruhi atau menjadi sebab perubahannya atau timbulnya variabel dependen (terikat) (Sugiyono, 2014). Variabel dependen dalam penelitian ini adalah kinerja perusahaan. 2) Variabel independen dalam penelitian ini adalah sistem informasi akuntansi dan sistem pengendalian internal. Dalam penelitian ini data yang dapat dihitung adalah jumlah jawaban kuisioner dari responden yaitu dari 531 orang dari 105 koperasi yang ada di Kecamatan Payangan sedangkan data kualitatif dalam penelitian ini adalah gambaran umum masing-masing koperasi yang ada di Kecamatan Payangan. Sumber data dalam penelitian ini menggunakan data primer, karena data diperoleh secara langsung dari sumber tanpa perantara.

Dalam penelitian ini populasi yang di ambil yaitu seluruh anggota dari 105 koperasi yang ada di Kecamatan Payangan. Maka jumlah populasi pada penelitian ini sebanyak 10.342 orang. Sampel yang digunakan dalam penelitian ini diambil dengan metode Purposive Sampling yang merupakan teknik penentuan sampel dengan pertimbangan tertentu. Pengambilan penentuan sampel dilakukan. Berdasarkan kriteria tertentu yaitu anggota koperasi yang menggunakan sistem informasi akuntansi pada koperasi yang masih aktif di Kecamatan Payangan.
Tabel 1

Jumlah Sampel

\begin{tabular}{lc}
\hline \multicolumn{1}{c}{ Kriteria } & Jumlah \\
\hline $\begin{array}{l}\text { Anggota yang menggunakan sistem } \\
\text { informasi akuntansi pada koperasi } \\
\text { yang masih aktif di Kecamatan }\end{array}$ & 531 orang \\
Payangan & \\
\multicolumn{1}{c}{ Jumlah Sampel } & orang \\
\hline
\end{tabular}

Metode pengumpulan data yang digunakan dalam penelitian ini adalah dengan membagikan daftar pertanyaan (kuesioner) yang akan diisi atau dijawab oleh responden. Pengumpulan data yang dibutuhkan guna mendukung penelitian ini menggunakan metode angket atau kuisioner. Teknik pengumpulan data dengan menggunakan kuisioner yang dilakukan dengan membawa kuisioner langsung ke lokasi penelitian Pada penelitian ini menggunakan skala likert, skala likert adalah skala yang dapat digunakan untuk mengukur sikap, pendapat, dan persepsi seseorang tentang suatu objek atau fenomena, bentuk jawaban skala likert terdiri dari "sangat setuju" sampai dengan "sangat tidak setuju". Urutan skala adalah sebagai berikut: Sangat Tidak Setuju (STS) diberi skor 1, Tidak Setuju (TS) diberi skor 2, Kurang Setuju (KS) diberi skor 3, Setuju (S) diberi skor 4 dan Sangat Setuju (SS) diberi skor 5.

Analisis data pada penelitian ini menggunakan beberapa teknik uji, Pertama Uji Instrumen yang terdiri dari; 1) Uji Validitas yang digunakan untuk mengukur sah atau tidak suatu kuesioner (Ghozali, 2016). Pengujian validitas ini menggunakan fasilitas SPSS. Pengukuran tinggi validitas ini dilakukan dengan cara melakukan korelasi antara skor butir pertanyaan dengan total skor variabel. Sedangkan total variabel diperoleh dengan menjumlahkan skor semua pertanyaan, sehingga dapat dinilai pearson correlation. Dasar pengambilan putusan yang valid atau tidaknya butir-butir pertanyaan dalam kuesioner adalah apabila total nilai dari person correlation untuk masing-masing butir pertanyaan menunjukkan nilai diatas 0,30 maka dapat dinyatakan valid. 2) Uji reliabilitas merupakan alat untuk mengukur suatu kuesioner yang merupakan indikator dari variabel atau konstruk. Suatu kuesioner dikatakan reliabel atau handal jika jawaban seseorang terhadap pernyataan adalah konsisten atau stabil dari waktu ke waktu (Ghozali, 2016). Dalam pengujian ini peneliti mengukur reliabelnya suatu variabel dengan cara melihat Cronbach Alpha 
dengan signifikansi yang digunakan lebih besar dari 0,70 .

Kedua, Dalam penelitian ini digunakan analisis linear berganda. Analisis ini digunakan karena peneliti ingin mengetahui bagaimana variabel terikat dapat diprediksikan melalui variabel bebas secara individual dengan kata lain untuk melihat pengaruh variabel bebas terhadap variabel terikat (Sugiyono, 2014). Hasil analisis regresi adalah berupa koefisien untuk masingmasing variabel independen. Regresi linear berganda didasarkan pada hubungan fungsional atau kausal satu variabel terkait dengan beberapa variabel bebas. Analisis regreai linear berganda digunakan untuk mengetahui pengaruh variabel bebas, yaitu pendidikan kewirausahaan, lingkungan keluarga, dan kebebasan dalam bekerja terhadap variabel dependen, yaitu motivasi berwirausaha. Persamaannya dapat dirumuskan sebagai berikut:

$$
\begin{array}{ll}
\mathrm{KP} & =\mathrm{a}+\beta_{1} \mathrm{SIA}+\beta_{2} \mathrm{SPI}+\mathrm{e} \\
\mathrm{KP} & =\text { Kinerja Perusahaan } \\
\alpha & =\text { Bilangan konstanta } \\
\beta_{1}-\beta_{2} & =\text { Koefisien arah persamaan penelitian } \\
\mathrm{SIA} & =\text { Sistem informasi akuntansi } \\
\mathrm{SPI} & =\text { Sistem pengendalian internal } \\
\mathrm{e} & =\text { kesalahan pengganggu }
\end{array}
$$

Ketiga, Uji asumsi klasik terhadap model regresi yang digunakan dalam penelitian ini adalah uji normalitas, uji multikolinearitas, dan uji heteroskedastisitas. Uji normalitas dilakukan untuk menguji apakah dalam sebuah model regresi, residu dari persamaan regresi mempunyai distribusi normal atau tidak (Ghozali, 2016). Model regresi yang baik adalah memiliki distribusi normal atau mendekati normal. Jika tidak normal, maka prediksi yang dilakukan dengan model tersebut akan tidak baik, atau dapat memberikan hasil prediksi yang menyimpang Uji normalitas dapat dilakukan dengan metode Kolmogorov-Smirnov. Caranya dengan membandingkan distribusi kumulatif relative hasil observasi dengan distribusi kumulatif teoritisnya (harapannya) atau Fcr (x). Dasar pengambilan keputusan pada metode Kolmogorov-Smirnov yaitu; 1) Jika nilai probabilitas nilai signifikan $\geq 0,05$ residual berdistribusi normal. 2) Jika nilai probabilitas nilai signifikan $\leq 0,05$ berarti data residual tidak berdistribusi normal.

Uji multikolinearitas bertujuan untuk menguji apakah pada model regresi ditemukan adanya korelasi antar variabel bebas (independen) (Ghozali, 2016). Model regresi yang baik seharusnya tidak terjadi korelasi diantara variabel independen. Untuk mendeteksi ada atau tidaknya multikolinearitas di dalam model regresi dapat dilihat dari nilai tolerance dan VIF (Variance Inflation Factor). Kedua ukuran ini menunjukkan setiap variabel independen manakah yang menjelaskan oleh variabel independen lainnya. Jika nilai tolerance $\geq 0,10$ atau VIF $\leq 10$, menunjukkan tidak ada multikolenearitas (Ghozali, 2016).

Uji heteroskedastisitas bertujuan menguji apakah dalam model regresi terjadi ketidakpastian variance dari residual satu pengamatan ke pengamatan yang lain (Ghozali, 2016). Jika variance satu pengamatan ke pengamatan lainnya tetap, maka disebut homoskedastisitas dan jika berbeda disebut heteroskedastisitas. Model regresi yang baik adalah yang homoskedastisitas atau tidak terjadi heteroskedastisitas. Cara pengujian ada tidaknya heteroskedastisitas dapat bermacam-macam diantaranya uji Glesjer. Pengujian ini dilakukan dengan meregresikan nilai residual terhadapvariabel independen. Jika variabel independen secara signifikan mempengaruhi variabel dependen, maka ada indikasi terjadi heteroskedastisitas atau sebaliknya. Kriteria pengujian ini jika nilai signifikan dari variabel independen lebih dari 0,05 maka tidak terjadi heteroskedastisitas, dan jika nilai signifikansi dari variabel independen lebih kecil dari 0,05 maka ada indikasi terjadi heteroskedastisitas (Ghozali, 2016).

Keempat, Uji Kelayakan Model terdiri dari 1) uji statistik $F$ pada dasarnya menunjukkan apakah semua variabel independen atau bebas yang dimasukkan dalam metode ini mempunyai pengaruh secara simultan atau secara keseluruhan terhadap variabel dependen atau terikat (Ghozali, 2016). Adapun kriteria pengambilan keputusan yang digunakan adalah jika profitabilitas $\geq 0,05$ maka variabel independen secara simultan atau secara keseluruhan berpengaruh terhadap variabel dependen. 2) Koefisien determinasi adjusted (R2) digunakan untuk mengetahui seberapa jauh kemampuan model dalam menerangkan variasi variabel dependen (Y). Pedoman untuk memberikan interpretasi koefisien korelasi yaitu : 0,00-0,199 = sangat rendah, $0,20-0,399=$ rendah , $0,40-0,599=$ sedang, $0,60-0,799=$ kuat, $0,80-$ $0,1000=$ sangat kuat. Penelitian ini menggunakan bantuan program SPSS untuk mengetahui 
besarnya koefisien determinasi adjusted (R2). 3) Uji statistik t disebut juga sebagai uji signifikan individual. Uji ini menunjukkan seberapa jauh berpengaruh variabel independen secara individu atau persial terhadap variabel dependen. Adapun kriteria pengambilan keputusan adalah; a) Jika signifikansi $\leq 0,05$, maka variabel independen berpengaruh terhadap variabel dependen. b) Jika signifikansi $\geq 0,05$, maka variabel independen tidak berpengaruh terhadap variable dependen.

\section{HASIL DAN PEMBAHASAN}

Tabel 2

Hasil Uji Validitas

\begin{tabular}{|c|c|c|c|c|}
\hline No & Variabel & Pertanyaan & Pearson Corellation & Keterangan \\
\hline \multirow{30}{*}{1.} & \multirow{20}{*}{$\begin{array}{c}\text { Sistem } \\
\text { Informasi } \\
\text { Akuntansi (X1) }\end{array}$} & $\mathrm{X} 1.1$ & 0,609 & Valid \\
\hline & & X1.3 & 0,400 & Valid \\
\hline & & $\mathrm{X} 1.7$ & 0,881 & Valid \\
\hline & & X1.8 & 0,552 & Valid \\
\hline & & X1.9 & 0,637 & Valid \\
\hline & & X1.10 & 0,617 & Valid \\
\hline & & X1.11 & 0,553 & Valid \\
\hline & & X1.12 & 0,881 & Valid \\
\hline & & X1.13 & 0,662 & Valid \\
\hline & & X1.14 & 0,738 & Valid \\
\hline & & X1.15 & 0,685 & Valid \\
\hline & & $\mathrm{X} 1.16$ & 0,567 & Valid \\
\hline & & X1.17 & 0,649 & Valid \\
\hline & & X1.18 & 0,712 & Valid \\
\hline & & X1.19 & 0,881 & Valid \\
\hline & & X1.20 & 0,881 & Valid \\
\hline & & X1.21 & 0,661 & Valid \\
\hline & & X1.22 & 0,645 & Valid \\
\hline & & X1.23 & 0,696 & Valid \\
\hline & & X1.24 & 0,741 & Valid \\
\hline & \multirow{20}{*}{$\begin{array}{c}\text { Sistem } \\
\text { Pengendalian } \\
\text { Internal (X2) }\end{array}$} & X1.25 & 0,436 & Valid \\
\hline & & X2.1 & 0,665 & Valid \\
\hline & & X2.2 & 0,363 & Valid \\
\hline & & $\mathrm{X} 2.3$ & 0,472 & Valid \\
\hline & & X2.4 & 0,467 & Valid \\
\hline & & X2.5 & 0,434 & Valid \\
\hline & & X2.6 & 0,854 & Valid \\
\hline & & X2.7 & 0,854 & Valid \\
\hline & & $\mathrm{X} 2.8$ & 0,854 & Valid \\
\hline & & X2.9 & 0,764 & Valid \\
\hline \multirow[t]{10}{*}{2.} & & X2.10 & 0,779 & Valid \\
\hline & & X2.11 & 0,672 & Valid \\
\hline & & X2.12 & 0,841 & Valid \\
\hline & & X2.13 & 0,854 & Valid \\
\hline & & X2.14 & 0,854 & Valid \\
\hline & & X2.15 & 0,854 & Valid \\
\hline & & X2.16 & 0,854 & Valid \\
\hline & & X2.17 & 0,854 & Valid \\
\hline & & X2.18 & 0,614 & Valid \\
\hline & & X2.19 & 0,560 & Valid \\
\hline
\end{tabular}


Pengaruh Sistem Informasi Akuntansi Dan Sistem Pengendalian Internal Terhadap Kinerja Perusahaan (Studi Kasus Pada Koperasi Di Kecamatan Payangan)

\begin{tabular}{|c|c|c|c|c|}
\hline & \multirow{52}{*}{$\begin{array}{c}\text { Kinerja } \\
\text { Perusahaan (Y) }\end{array}$} & Y1.1 & 0,515 & Valid \\
\hline & & Y1.7 & 0,953 & Valid \\
\hline & & Y1.8 & 0,452 & Valid \\
\hline & & Y1.9 & 0,490 & Valid \\
\hline & & Y1.10 & 0,490 & Valid \\
\hline & & Y1.11 & 0,389 & Valid \\
\hline & & Y1.12 & 0,953 & Valid \\
\hline & & Y1.13 & 0,552 & Valid \\
\hline & & Y1.14 & 0,641 & Valid \\
\hline & & Y1.15 & 0,567 & Valid \\
\hline & & Y1.16 & 0,440 & Valid \\
\hline & & Y1.17 & 0,453 & Valid \\
\hline & & Y1.18 & 0,587 & Valid \\
\hline & & Y1.19 & 0,953 & Valid \\
\hline & & Y1.20 & 0,953 & Valid \\
\hline & & Y1.21 & 0,528 & Valid \\
\hline & & Y1.22 & 0,503 & Valid \\
\hline & & Y1.23 & 0,585 & Valid \\
\hline & & Y1.24 & 0,590 & Valid \\
\hline & & Y1.25 & 0,953 & Valid \\
\hline & & Y1.26 & 0,953 & Valid \\
\hline & & Y1.27 & 0,953 & Valid \\
\hline & & Y1.28 & 0,953 & Valid \\
\hline & & Y1.29 & 0,953 & Valid \\
\hline & & Y1.30 & 0,953 & Valid \\
\hline & & Y1.31 & 0,953 & Valid \\
\hline & & Y1.32 & 0,953 & Valid \\
\hline & & Y1.33 & 0,953 & Valid \\
\hline & & Y1.34 & 0,953 & Valid \\
\hline & & Y1.35 & 0,953 & Valid \\
\hline & & Y1.36 & 0,953 & Valid \\
\hline & & Y1.37 & 0,953 & Valid \\
\hline & & Y1.38 & 0,953 & Valid \\
\hline & & Y1.39 & 0,953 & Valid \\
\hline & & Y1.40 & 0,953 & Valid \\
\hline & & Y1.41 & 0,953 & Valid \\
\hline & & Y1.42 & 0,953 & Valid \\
\hline & & Y1.43 & 0,953 & Valid \\
\hline & & Y1.44 & 0,953 & Valid \\
\hline & & Y1.45 & 0,953 & Valid \\
\hline & & Y1.46 & 0,953 & Valid \\
\hline & & Y1.47 & 0,953 & Valid \\
\hline & & Y1.48 & 0,953 & Valid \\
\hline & & Y1.49 & 0,953 & Valid \\
\hline & & Y1.50 & 0,953 & Valid \\
\hline & & Y1.51 & 0,953 & Valid \\
\hline & & Y1.52 & 0,953 & Valid \\
\hline & & Y1.53 & 0,953 & Valid \\
\hline & & Y1.54 & 0,953 & Valid \\
\hline & & Y1.55 & 0,953 & Valid \\
\hline & & Y1.56 & 0,953 & Valid \\
\hline & & Y1.57 & 0,953 & Valid \\
\hline
\end{tabular}


Berdasarkan hasil uji validitas diatas, dapat disimpulkan bahwa beberapa item yang digunakan dalam penelitian ini adalah valid. Hal ini bisa dilihat dari masing-masing pertanyaan memiliki nilai Corrected Item-Total Correlatian yang lebih besar dari 0,30 . Sedangkan beberapa item dari variabel $\mathrm{X} 1$ nomor $2,4,5$ dan 6 , serta item dari variabel $\mathrm{Y}$ nomor $2,3,4,5$, dan 6 dikeluarkan karena tidak valid.

Tabel 3

Hasil Uji Reliabilitas

\begin{tabular}{cccc}
\hline No & Variabel & Conhach Alpha & Keterangan \\
\hline 1. & Sistem Informasi Akuntansi (X1) & 0,918 & Reliabel \\
2. & Sistem Pengendalian Internal (X2) & 0,836 & Reliabel \\
3. & Kinerja Perusahaan (Y) & 0,973 & Reliabel \\
\hline
\end{tabular}

Berdasarkan penjelasan yang telah menunjukkan bahwa masing-masing variabel dikemukakan bahwa, apabila nilai Cronbach adalah reliabel, karena masing-masing variabel Alpha lebih besar daro 0,70 maka instrument memiliki skor lebih dari 0,70. tersebut dikatakan reliabel. Pada tabel 3 diatas

Tabel 4

Hasil Uji Analisis Regresi Linear Berganda

\begin{tabular}{cccccc}
\hline \multirow{2}{*}{ Model } & Unstandarized Coefisients & \multicolumn{2}{c}{ Standarized Coefisients } & \multirow{2}{*}{$\mathrm{t}$} & \multirow{2}{*}{ Sig. } \\
& $\mathrm{B}$ & $\mathrm{Std}$. Error & Beta & 17,342 & 0,000 \\
(Constant) & 152,234 & 8,778 & & 1,173 & 0,242 \\
KSIA & 0,062 & 0,052 & 0,065 & 7,758 & 0,000 \\
SPI & 0,701 & 0,090 & 0,429 & 0 \\
\hline
\end{tabular}

Berdasarkan tabel diatas pada kolom Unstandarized Coefisients bagian B diperloleh model persamaan moderated regression analysis yaitu:

$\mathrm{KP}=152,234+0,062 \mathrm{KSIA}+0,701 \mathrm{SPI}$

$\alpha=152,234$ artinya jika $\mathrm{X} 1$ dan $\mathrm{X} 2$ sama dengan nol, maka kinerja perusahaan (Y) sebesar 152,234 $\beta_{1}=0,062$ dengan sig. 0,242 lebih besar dari 0,05 maka sistem informasi akuntansi tidak berpengaruh terhadap kinerja perusahaan

$\beta_{2}=0,701$ artinya jika variabel sistem pengendalian internal bertambah satuan maka kinerja perusahaan akan mengalami kenaikan sebesar 0,701 dengan syarat X1 konstan.

Tabel 5

Hasil Uji Normalitas

One-Sample Kolmogorov-Smirnov Test

\begin{tabular}{llc}
\hline & & Unstandarsdiz ed Residual \\
\hline $\mathrm{N}$ & & 283 \\
Normal Parameters & Mean & 0,0000000 \\
& Std. Deviation & 2,93114310 \\
Most Extreme Differences & Absolute & 0,101 \\
& Positive & 0,101 \\
& Negative & $-0,074$ \\
Kolmogorov-Smirnov Z & & 0,697 \\
Asymp. Sig. (2-tailed) & & 0,763 \\
\hline
\end{tabular}

Berdasarkan tabel diatas menunjukkan hasil bahwa nilai Kolmogorov Smirnof Z sebesar 0,697 sedangkan nilai Asymp. Sig (2-tailed) sebesar 0,763 . Hasil tersebut mengindikasikan bahwa persamaan regresi berdistribusi normal karena nilai Asymp. Sig (2-tailed) 0,763 lebih besar dari alpha 0,05 .

Tabel 6

Hasil Uji Multikolinearitas

\begin{tabular}{crr}
\hline \multirow{2}{*}{ Model } & \multicolumn{2}{c}{ Colinearity Statistics } \\
& Tolerance & VIF \\
\hline (Constant) & 0,963 & \\
KSIA & 0,963 & 1,039 \\
SPI & 1,039 \\
\hline
\end{tabular}


Berdasarkan tabel diatas menunjukkan bahwa nilai tolerance dari variabel bebas (independen) $\geq$
0,10 dan $\mathrm{VIF} \leq 10$, maka dapat disimpulkan bahwa tidak terjadi multikolinearitas.

Tabel 7

Hasil Uji Heteroskedastisitas

\begin{tabular}{cccccc}
\hline Model & Sum of Squares & Df & Mean Square & F & Sig. \\
\hline Regresion & 521,798 & 2 & 260,899 & \multirow{2}{*}{30,151} & 0,000 \\
Residual & 2422,831 & 280 & 8,653 & & \\
Total & 2944,629 & 282 & 896 \\
\hline
\end{tabular}

Berdasarkan tabel diatas menunjukkan bahwa semua variabel bebas memiliki nilai signifikansi yaitu 0,294 dan 0,591 menunjukkan hasil bahwa

nilai signifikansinya $>0,05$ maka dapat disimpulkan bahwa tidak terdapat gejala heteroskedastisitas

Tabel 8

Hasil Uji F

\begin{tabular}{cccccc}
\hline Model & Sum of Squares & Df & Mean Square & F & Sig. \\
\hline Regresion & 521,798 & 2 & 260,899 & 30,151 & $0,000^{\mathrm{a}}$ \\
Residual & 2422,831 & 280 & 8,653 & & \\
Total & 2944,629 & 282 & & \\
\hline
\end{tabular}

Berdasarkan tabel di atas diperoleh nilai Maka model regresi dikatakan fit atau layak signifikansi 0,000 yang lebih kecil dari 0,05 . untuk menguji selanjutnya

Tabel 9

Hasil Uji Koefisien Determinasi

\begin{tabular}{ccccc}
\hline Model & R & R Square & Adjusted R Square & Std. Error of the Estimate \\
\hline 1 & $0,421^{\text {a }}$ & 0,177 & 0,171 & 2,94159 \\
\hline
\end{tabular}

Berdasarkan tabel di atas menyajikan nilai oleh variabel sistem informasi akuntansi dan koefisien determinasi (Adjusted R2) adalah 0,171 atau sebesar 17,1 persen. Hal ini berarti kinerja perusahaan mampu dijelaskan sebesar 17,1 persen sistem pengendalian internal. Sedangkan sisanya 82,9 persen dipengaruhi oleh faktor-faktor lain yang tidak dimasukkan kedalam model penelitian.

Tabel 10

Hasil Uji t

\begin{tabular}{cccccccc}
\hline Model & \multicolumn{2}{c}{ Unstandarized Coefisients } & $\begin{array}{c}\text { Standarized } \\
\text { Coefisients }\end{array}$ & T & Sig. & \multicolumn{2}{c}{ Colinearity Statistics } \\
& $\mathrm{B}$ & Std. Error & Beta & & & Tolerance & VIF \\
\hline (Constant) & 152,234 & 8,778 & & 17,342 & 0,000 & 0,963 & 1,039 \\
KSIA & 0,062 & 0,052 & 0,065 & 1,173 & 0,242 & 0,963 & 1,039 \\
SPI & 0,701 & 0,090 & 0,429 & 7,758 & 0,000 & &
\end{tabular}

Berdasarkan Tabel diatas dapat dijelaskan bahwa:

Pengaruh sistem informasi akuntansi terhadap kinerja perusahaan; Variabel sistem informasi akuntansi menunjukkan nilai $t$ hitung sebesar 1,173 dengan nilai signifikansi 0,242 dimana nilai tersebut lebih besar dari 0,05 sehingga sistem informasi akuntansi tidak berpengaruh terhadap kinerja perusahaan maka hipotesis ditolak.

Pengaruh sistem pengendalian iternal terhadap kinerja perusahaan; Variabel sistem pengendalian internal menunjukkan nilai $\mathrm{t}$ hitung sebesar 7,758 dengan nilai signifikansi 0,000 dimana nilai tersebut lebih kecil dari 0,05 sehingga sistem pengendalian internal berpengaruh positif terhadap kinerja perusahaan maka hipotesis diterima.

\section{SIMPULAN}

Penelitian ini bertujuan untuk mengetahui apakah sistem informasi akuntansi dan sistem pengendalian internal berpengaruh terhadap kinerja perusahaan. Dalam penelitian ini populasi dan sampel yang digunakan adalah 531 anggota koperasi yang bekerja pada koperasi di Kecamatan Payangan. Untuk menganalisis data 
menggunakan teknik analisis regresi linear berganda. Hasil penelitian menyebutkan Sistem informasi akuntansi tidak berpengaruh terhadap kinerja perusahaan pada koperasi di Kecamatan Payangan dan Sistem pengendalian internal berpengaruh positif terhadap kinerja perusahaan pada koperasi di Kecamatan Payangan.

\section{DAFTAR PUSTAKA}

Ajzen, I., \& Fishbein, M. (1980). Understanding Attitudes and Predicting Social Behavior. New Jersey: Prentice Hall.

Bodnar, G. H., \& Hopwood, W. S. (2003). Sistem Informasi Akuntansi, Edisi 8. Jakarta: Salemba Empat.

Chairany, N., \& Lestari, W. P. (2011). Pengaruh Total Quality Management Terhadap Kinerja Perusahaan Melalui Kepemimpinan Dan Perilaku Produktif Karyawan. Fakultas Ekonomi Universitas Hasanuddin Makassar. Retrieved from http:// repository.unhas.ac.id/handle/123456789/461

Davis, F. D. (1989). Perceived Usefulness, Perceived Ease of Use, and User Acceptance of Information Technology. MIS Quarterly, 13(3), 319-340. Retrieved from https://pdfs.semanticscholar.org/ ea34/9162d97873d4493502e205968ffccb23fcf2.pdf? $\mathrm{ga}=2.88152283 .1311680478 .1575336000$ 2011102063.1569380637

Diana, A., \& Setiawati, L. (2011). Sistem Informasi Akuntansi: Perancangan, Proses, dan Penerapan. Yogyakarta: Andi Offseet. Retrieved from http:// library.um.ac.id/free-contents/index.php/buku/detail/ sistem-informasi-akuntansi-perancangan-proses-danpenerapan-anastasia-diana-lilis-setiawati-43453.html

Ghozali, I. (2016). Aplikasi Analisis Muttivariate dengan Program SPSS 23. Cetakan VIII. Semarang: Badan Penerbit Universitas Diponogoro.

Halim, A. (2008). Auditing (Dasar-dasar Audit Laporan Keuangan). Yogyakarta: Badan Penerbit Sekolah Tinggi Ilmu Manajemen Yayasan Keluarga Pahlawan Negara.

Hall, J. A. (2001). Sistem Informasi Akuntansi, Edisi Ketiiga,. Jakarta: Salemba Empat.

Helfert, E. (1996). Teknik Analisis Keuangan (Petunjuk Praktis Untuk Mengelola Dan Mengukur Kinerja Perusahaan), Edisi 8. Jakarta: Erlangga.

Jensen, M. C., \& Meckling, W. H. (1976). Theory of the firm: Managerial behavior, agency costs and ownership structure. Journal of Financial Economics, 3(4), 305-360. Retrieved from https:// doi.org/10.1016/0304-405X(76)90026-X

Kaplan, R. S., \& Norton, D. P. (1996). Balanced Scorecard. Jakarta: Erlangga. Retrieved from https:// onesearch.id/Record/IOS2723.ai:slims-38777

Moeheriono. (2012). Pengukuran Kinerja Berbasis Kompetensi. Jakarta: Rajawali Press.

Mulyadi. (2002). Auditing (Buku Dua), Edisi ke Enam. Jakarta: Salemba Empat.

Munawir. (2000). Analisis Laporan Keuangan, Edisi Ketiga. Yogyakarta: Liberty.

Romney, M. B., \& Steinbart, P. J. (2015). Sistem Informasi Akuntansi. Jakarta: Salemba Empat.
Schuler, R. S., \& Jackson, S. E. (1996). Manajemen Sumber Daya ManusiaMenghadapi Abad ke 21, Jilid 2, Edisi Keenam. Jakarta: Erlangga.

Sugiyono. (2014). Metode Penelitian Kuantitatif, Kualitatif dan $R \& D$. Bandung: Alfabeta.

Susanto, I., Taman, A., \& Sukirno. (2004). Balanced Scorecard Sebagai Alat Pengukuran Kinerja Manajemen (Studi Kasus Pada PT Sari Husada). Jurnal Pendidikan Akuntansi Indonesia, 3(1). Retrieved from https://doi.org/10.21831/ jpai.v3i1.833

Suswardji, E., Hasbullah, R., \& Albatross, E. (2012). Hubungan Kompetensi Dan Disiplin Kerja Terhadap Kinerja Tenaga Kependidikan Universitas Singaperbangsa Karawang. Jurnal Manajemen, 10 (1), 955-979. 